\title{
College English Teaching According to Students' Goals of Study
}

\author{
Yan $\operatorname{Jun}^{1}$ \\ ${ }^{1}$ Foreign Language Department, Sichuan University of Science \& Engineering, Zigong, Sichuan, China \\ Correspondence: Yan Jun, Foreign Language Department, Sichuan University of Science \& Engineering, Zigong, \\ Sichuan, China. Tel: 86-813-550-5882. E-mail: popococo51@hotmail.com
}

Received: August 11, 2015 Accepted: September 26, 2015 Online Published: October 29, 2015

doi:10.5430/ijelt.v3n1p50 URL: http://dx.doi.org/10.5430/ijelt.v3n1p50

\begin{abstract}
Ministry of Education of the People's Republic of China attaches great importance to College English, and calls for teaching in accordance with students' aptitude. To meet the requirements of Ministry of Education, many colleges and universities apply the graded teaching mode. They divide students into different grades according to their English levels, and suit the teaching to the students' English levels of each grade. However, this mode of teaching has some weaknesses. And because of the great differences among universities and colleges in China, the teaching reforms of some key universities could not be applied to some other universities and colleges. Therefore, the research group carried out a survey in Sichuan University of Science \& Technology on the students' English proficiency, their goals of learning English, views on English graded teaching, responses to the current English course and their views on the reform of the course.. Based on the result of the survey, the research group puts forward a new teaching mode - college English teaching according to students' goals of study, which can be well applied to non-key universities. This teaching mode could make teaching cater to the students' personal goals of study, without doing harm to their study enthusiasm.
\end{abstract}

Keywords: college English, goals of study, general requirements

\section{Introduction}

College English is a compulsory public course in colleges and universities in China, and it has been given great importance by Ministry of Education of the People's Republic of China. In the College English Curriculum Teaching Requirements (trial implementation) issued by Division of Higher Education of Ministry of Education, it is put forward that "because of the vast territory of our country, and the great differences among different regions and universities or colleges, the principle of guidance according to the different student proficiency levels and teaching in accordance with their aptitude should be applied to achieve the goal of individualized teaching. College English requirements for students are divided into three levels: general requirements, high requirements and higher requirements"(Ministry of Education of the People's Republic of China, 2004).

To meet the requirements of the Ministry of Education, many colleges and universities apply graded teaching mode. After taking the exam for graded teaching, students are divided into different grades according to their scores. Students who are poor at English are put into low level grade, and other students are put into the middle level grade or high level grade. Although graded teaching can be helpful in developing methods for students of different proficiency levels, it could have some weaknesses. Firstly, "the enthusiasm of the students who are put into the low level grade may be dampened" (You Honglan, 2011). Secondly, "the basic goal of college English graded teaching is to improve students' English proficiency, and encourage the students who are poor at English to study hard to get into the middle level grade or high level grade. So the number of students in high level grade could be increased. However, in the college English graded teaching system, this goal is not fully achieved. The vast majority of students who are poor at English still remain in the low level grade, and their English is not obviously improved in college"(You Honglan, 2011). Moreover, a closer study of the College English Curriculum Teaching Requirements (trial implementation) reveals that the graded teaching mode could not fully achieve the aim of the Requirements. The Requirements points out clearly that "the general requirements are the goal that every college graduate must achieve. College freshmen who have or have not reached the seventh level of the Standard of High School English Curriculum could make the general requirements the goal of their College English learning" (Ministry of Education 
of China, 2004). The Requirements also emphasizes that "general requirements are the basic requirements for non-English Majors in Colleges and Universities." "Higher and higher requirements are for those students who have better capacity, good English basis, and have reached the eighth or ninth level of the Standard of High School English Curriculum." "Colleges and universities should determine the teaching objectives based on the actual situation of the school, and create conditions to encourage students to adjust their learning objectives according to their own English levels to meet the high requirements or higher requirements" (Ministry of Education of China,2004).

However, the graded teaching of most universities and colleges means to divide students into three or four level grades according to their test scores, including the level grade for "high requirements" and the level grade for "higher requirements", to enter which, students need to get required scores. For example, Southwest University places students into three level grades: the primary level grade, the middle level grade and the high level grade. The requirements of the middle level grade are equal to the general requirements of the Ministry of the Education. Yangzhou University also divides students into three level grades: the general requirement level grade, the high requirement level grade, the higher requirement level grade. Students of the general requirement level grade are demanded to choose the comprehensive basic course from the first term to the fourth term, and only until the fifth term, can they choose extending courses; students of the high requirement level grade are demanded to choose the comprehensive basic course from the first term to the third term, and then they can choose extending courses; students of the higher requirement level grade are demanded to choose the comprehensive basic course in the first and second terms, and then they can choose extending courses in the third and fourth term.

This level grade division forces the students to study hard to enter the higher level grade and puts great pressure on them like the division of adjustment classes and standard classes in middle school. Although it gives great impetus to students' English study, it disencourages some students who are bad at English, and deprives the fun of English learning. At the same time, this level-promotion mode makes the students' purpose of learning English unclear, and does not cater to the students' interest in English learning. So, although this mode is student-oriented to some degree, it is not fully humanized.

To change this situation, many scholars conducted research on college English teaching. For instance, professor Cai Jigang in Fudan University proposes that as the English proficiency of high school graduates are being greatly improved, most of the goals of general college English teaching will be achieved in high school, so universities with conditions, especially key universities, should try to make the focus of College English teaching gradually shifted to the teaching direction of ESP (Cai Jigang, 2004).

Besides, quite a few of colleges and universities have carried out reforms according to their own characteristics. For example, Fudan University and Shanghai Jiaotong University have credit selective systems. The system is a combination of college English compulsory courses and selective courses. Zhejiang University has ESP teaching. University of Shanghai for Science and Technology has three dimensional, multi-level college English courses which include 29 extending college English courses. However, because in different universities and colleges, students' English proficiency, facilities, quality of professors or lecturers are different, the successful reforms of some key universities and colleges could not be well applied to other universities and colleges. Therefore, to find a college English teaching mode that can be applied to non-key universities in the west of China, like Sichuan University of Science and Technology, this research group conducted a survey of non-English major students of Sichuan University of Science and Technology to acquire a clear idea of the students' English proficiency and goals of English study, views on English graded teaching, and responses to the current English course and views on the reform of the course.

\section{The Survey}

The survey was conducted in April 2014, in the form of stratified sampling. 200 first and second year college students majoring in food safety, pharmacy, and civil engineering were selected as the research objects. The survey was carried out with a questionnaire, which was designed by the research group after they consulted relevant researches at home and abroad. Before the survey was carried out formally, a pilot survey was made, and the questionnaire was revised according to the feedback. The final questionnaire is composed of three parts. The first part is the investigation on students English proficiency and goals of learning English, including 4 questions; the second part is to investigate the students' views on English graded teaching, including 3 questions; the third part is the investigation of the students' responses to the current English course and their views on the reform of the course, including 7 questions. Each question requires a single choice. The questionnaire survey was conducted in the ninth 
week of the latter half of the school year. At that time, 3/4 of the task of college English teaching for both the first year students and the second year students had been finished, so the students had come to know college English teaching and could give a feedback on their learning and demands. Besides, to ensure the validity of the survey, it was explained to the students that they do not need to sign their name on the questionnaire and the questionnaire would only be used for research purposes and would not affect their exam scores. In the survey, 200 questionnaires were sent out, and 193 valid questionnaires were returned. The result of the survey is presented in the following charts.

\section{Results}

Table 1. The Students' English Proficiency and Goals of English Study

\begin{tabular}{|c|c|c|c|}
\hline Questions & Choices & $\begin{array}{l}\text { Percentages of the } \\
\text { first year students }\end{array}$ & $\begin{array}{l}\text { Percentages of the } \\
\text { second year students }\end{array}$ \\
\hline \multirow{4}{*}{$\begin{array}{l}\text { Marks of English } \\
\text { college entrance } \\
\text { examination (the } \\
\text { total mark is 150) }\end{array}$} & Below 90 & $23 \%$ & $19 \%$ \\
\hline & $90-100$ & $51 \%$ & $36 \%$ \\
\hline & $100-120$ & $21 \%$ & $39 \%$ \\
\hline & Over 120 & $5 \%$ & $6 \%$ \\
\hline \multirow{2}{*}{$\begin{array}{l}\text { Whether has past the } \\
\text { band } 4 \text { test }\end{array}$} & Yes & $12 \%$ & $33 \%$ \\
\hline & No & $88 \%$ & $67 \%$ \\
\hline \multirow{4}{*}{$\begin{array}{l}\text { Goals of English } \\
\text { study }\end{array}$} & To past band 4 and band 6 tests & $74 \%$ & $62 \%$ \\
\hline & To past the final exam & $10 \%$ & $10 \%$ \\
\hline & $\begin{array}{l}\text { To learn English and American } \\
\text { culture }\end{array}$ & $11 \%$ & $22 \%$ \\
\hline & To learn English the language & $5 \%$ & $6 \%$ \\
\hline
\end{tabular}

Table 2. Students' Views on Graded Teaching

\begin{tabular}{|l|l|l|l|}
\hline Questions & Choices & $\begin{array}{l}\text { Percentages of the first } \\
\text { year students }\end{array}$ & $\begin{array}{l}\text { Percentages of the second } \\
\text { year students }\end{array}$ \\
\hline $\begin{array}{l}\text { Whether graded } \\
\text { teaching is good for }\end{array}$ & It is good for it. & $69 \%$ & $78 \%$ \\
\cline { 2 - 4 } $\begin{array}{l}\text { English learning? } \\
\text { Are you willing to }\end{array}$ & It is bad for it. & $31 \%$ & $22 \%$ \\
\cline { 2 - 4 } $\begin{array}{l}\text { be put to the low } \\
\text { level grade? }\end{array}$ & Wot willing to & $58 \%$ & $48 \%$ \\
\hline $\begin{array}{l}\text { Influence of graded } \\
\text { teaching on study } \\
\text { enthusiasm of } \\
\text { students. }\end{array}$ & Encouraging & $20 \%$ & $52 \%$ \\
\cline { 2 - 4 } & Disencouraging & $58 \%$ & $32 \%$ \\
\cline { 2 - 4 } & No influence & $22 \%$ & $25 \%$ \\
\hline
\end{tabular}

Table 3. Students' Views on the Current English Course and Views on the Reform of the Course

\begin{tabular}{|l|l|l|l|}
\hline Questions & Choices & $\begin{array}{l}\text { Percentages of } \\
\text { the first year } \\
\text { students }\end{array}$ & $\begin{array}{l}\text { Percentages of } \\
\text { the } \\
\text { second } \\
\text { year students }\end{array}$ \\
\hline \multirow{2}{*}{$\begin{array}{l}\text { Whether the current English } \\
\text { course is helpful for students to }\end{array}$} & very helpful & $6 \%$ & $4 \%$ \\
\cline { 2 - 5 } & helpful & $47 \%$ & $35 \%$ \\
\hline
\end{tabular}




\begin{tabular}{|l|l|l|l|}
\hline \multirow{2}{*}{ improve their English? } & a little helpful & $31 \%$ & $35 \%$ \\
\cline { 2 - 4 } & not helpful & $16 \%$ & $26 \%$ \\
\hline \multirow{2}{*}{$\begin{array}{l}\text { Are you willing to take different } \\
\text { English skill courses and culture } \\
\text { selective courses? }\end{array}$} & yes & $67 \%$ & $78 \%$ \\
\cline { 2 - 4 } & no & $14 \%$ & $4 \%$ \\
\cline { 2 - 4 } & indifferent & $19 \%$ & $18 \%$ \\
\hline $\begin{array}{l}\text { Selective courses that should be } \\
\text { offered in the first year and } \\
\text { second year include: }\end{array}$ & \begin{tabular}{l} 
basic technique $\begin{array}{l}\text { courses(listening, grammar, and } \\
\text { so on ) }\end{array}$ \\
\cline { 2 - 4 }
\end{tabular} & $54 \%$ & $43 \%$ \\
\cline { 2 - 4 } & courses about culture & $16 \%$ & \\
\cline { 2 - 4 } & band test training courses & $29 \%$ & $18 \%$ \\
\cline { 2 - 4 } & ESP courses & $1 \%$ & $32 \%$ \\
\hline \multirow{2}{*}{$\begin{array}{l}\text { Would you like to continue to } \\
\text { study English in the third year } \\
\text { and the fourth year? }\end{array}$} & yes & $62 \%$ & $5 \% \%$ \\
\cline { 2 - 4 } $\begin{array}{l}\text { Selective English course should } \\
\text { be offered in the third year and } \\
\text { the fourth year include: }\end{array}$ & basic technique training courses & $13 \%$ & $45 \%$ \\
\cline { 2 - 4 } & Courses about culture & $59 \%$ & $14 \%$ \\
\cline { 2 - 4 } & band test training courses & $14 \%$ & $54 \%$ \\
\cline { 2 - 4 } & ESP courses & $14 \%$ & $14 \%$ \\
\hline
\end{tabular}

As a second class undergraduate college of science and engineering, the situation in our school can roughly represent that of other similar colleges and universities in the west of China.

From the result of the survey, it could be seen, firstly, the English proficiency of students in Sichuan University of Science \& Technology is not good, and it could be much worse than that of students in college and universities of coastline areas, especially those key universities.

Secondly, it could be seen that the students' past rates of band 4 test in the first year and the second year students are both below 5\%. Although the past rate of the second year students is a little higher than that of first year students, the improvement is very small. Students' weak English basis is an important reason for that, but the ineffectiveness of teaching can also be a reason.

Thirdly, the survey shows that more than $60 \%$ students study English to pass band 4 and band 6 tests, and only a small amount of students study English because they want to learn English the language or British and American culture. So, it is obvious that the students are practical, but they are also shortsighted. That is probably because of the education they got in high school, but that also indicates that in college English teaching, culture does not have enough influence on students.

Fourthly, the survey shows that $70 \%$ of students think that graded teaching can help them improve their English, but above $50 \%$ of students are not willing to be put into the low level grade, and about $50 \%$ of students think that graded teaching can do harm to their enthusiasm in study. Therefore, it could be concluded that although students think that graded teaching is helpful, physiologically, they could not fully accept it. So, the weakness of graded teaching is obvious.

Then, in the survey, $47 \%$ first year students think that the current English course is a little helpful or not helpful for them to improve their English, and up to $61 \%$ of second students think so. So, it could be concluded that students are not quite satisfied with the current college English course, and the longer they have the English course, the less they are satisfied with it. Therefore, the reform of it must be carried out.

At last, it could be seen that more than $60 \%$ of first year students and $70 \%$ of second year students are willing to have English selective courses. And half of the students think that basic technique training courses should be offered in the first and second year; about 30\% students think that band test training courses should be offered. About $55 \%$ students are willing to have English selective course in the third and fourth year, and they think culture and literature courses should be offered. Only 14\% students think that ESP English courses should be offered in the third and 
fourth year.

To sum up, the survey indicates that compared with students in key universities, students in universities and colleges like Sichuan University of Science and Technology have weak English basis, and are resistive to graded teaching to some degree. To past band 4 and band 6 tests is still their main reason for English study, but they are enthusiastic in English selective courses. Therefore, the reform of the college English course in this universities and colleges could not be the same as the reform in those key universities. It should be adapted to the students requirements and English proficiency of those colleges and universities.

\section{College English Teaching According to Students' Goals of Study}

With meticulous study on the survey and relevant information, the research group establishes a new teaching mode - teaching according to students' goals of study, which can be adapted to students of different English proficiency, meet their requirements for selective course, and satisfy their needs for different study goals.

Teaching according to students' goals of study means to teach students according their different study goals. It is different from graded teaching for it does not divide students into different grades according to their test scores. So it would not harm students' study enthusiasm, and at the same time it can offer students different compulsory and selective courses to make teaching individualized. Because of the flexibility of this teaching mode, it can be applied to universities like Sichuan University of Science and Technology, as well as many similar universities and colleges in the west of China.

To provide college English teaching according to students' goals of study, universities or colleges should offer different compulsory and selective English courses according to their own characteristics and their students' need, and a "general requirements" test should be held every year. All the students can choose to take the test. If the student passes the test, he or she meets the "general requirements", so he or she could end the study in the compulsory college English basic course and decide by himself or herself what he or she wants to learn and achieve.

The student may choose to meet the demands of "high requirements" or "higher requirements" by taking selective English courses, like English interpretation, ESP courses and so on. However, he or she can also choose not to meet those demands, and choose courses related to band 4 and band 6 tests to just pass those tests, or choose culture or literature courses like intercultural communication and English literature to enlarge his or her knowledge scope, or choose courses like business spoken English and business English writing to prepare himself or herself for future work. If the student is not interested in English, after he or she passes the "general requirements" test, he or she could end his or her English study, and choose other courses to get enough credits for graduation. The students who fail the "general requirements" test have to continue to take the basic college English course, until they pass the test. But at the same time, they can choose some basic English selective courses to help them pass the test. After they pass the test, they can also choose other selective courses. In this way, the negative influence of graded teaching can be avoided, and English teaching can be well student-oriented. To achieve that, the university needs to open up different selective courses that students need.

As a non-key science and engineering university, our university's college English curriculum could be programmed in the following way to make teaching in accordance with students' goals of study. Firstly, the total credits of college English courses are 16 . The credits of the compulsory course could be reduced to 8 . The rest 8 credits should be assigned to selective courses. In the basic stage, selective courses may include listening, reading, grammar and writing. In the advanced stage, selective courses may include inter-cultural communication, practical English writing, British and American society and culture, and so on. And selective courses of the basic stage and advanced stage should be offered at the same time, so students could make different choices according to their needs. In addition, the "general requirements" test should be held each year, and only the students who have passed the test could choose selective courses of the advanced stage. Students who haven't passed the test can only choose selective courses in the basic stage. In this way, teachers could teach students in accordance with their aptitude and the students' basic language skills could be well cultivated. Moreover, students' different goals of study could be well taken into consideration, and college English teaching can become individualized.

\section{Conclusion}

To sum up, various reforms on college English teaching have been carried out in different universities and colleges in China, but because of the large amount of universities and colleges and great differences existing among them, 
college English teaching still asks for new reforms. Although graded teaching still seems a relatively advanced way of college English teaching, it demands improvement to take care of students' study enthusiasm, and personal study goals. Teaching according to students' goals of study would not dampen students study enthusiasm and can well cater to students' personal study goals by offering different English and other selective courses, while ensuring that students can meet the "general requirements" put forward by Ministry of Education of China. By this means, distinctive talents can be cultivated through different college English curriculums.

\section{References}

Cai Jigang. (2004). ESP and the development direction of College English Teaching in China. English World, 100, 22-28.

Ministry of Education of China. (2004). College English Curriculum Teaching Requirements (trial implementation).

You Honglan, Li Lihua, \& Zhang Shijun. (2011). Exploration of College English Graded Teaching. Examination Weekly, 20, 119-120. 